\title{
PENGARUH PENDIDIKAN DAN PELATIHAN, KOMITMEN DAN KOMPETENSI TERHADAP PROMOSI JABATAN DI PT. PANARUB INDUSTRY TANGERANG
}

\author{
Agus Yulistiyono \\ Dosen Fakultas Ekonomi dan Bisnis Program Studi Manajemen \\ Universitas Muhammadiyah Tangerang
}

\begin{abstract}
ABSTRAK
Salah satu kemajuan suatu bangsa dapat diukur dari sumber daya manusianya. Dimana kemajuan sumber daya manusia dapat dilihat dari pencapaian pendidikan dan ini dapat dilihat dari Human Development Index in PECC Economies pada kolom Educational Attainment. Oleh sebab itu pendidikan merupakan salah satu bidang yang sangat penting dalam kehidupan suatu bangsa, terpuruknya perekonomian yang mengakibatkan rakyat banyak kehilangan kesempatan untuk menikmati pendidikan baik formal maupun nonformal sehingga bidang pendidikan merupakan salah tujuan program pemerintah.

Melalui Departement Training And People Development dengan menyelenggarakan pendidikan dan pelatihan kualitas sumber daya manusia dapat ditingkatkan. Dengan pendidikan dan pelatihan, komitmen dan kompetensi yang dimiliki oleh karyawan diharapkan dapat mempromosikan dirinya untuk meningkatkan promosi jabatan yang lebih tinggi sesuai dengan kriteria dan kebutuhan perusahaan.
\end{abstract}

Kata Kunci : Pendidikan, Pelatihan, Komitmen, Kompetensi, Promosi Jabatan.

\section{PENDAHULUAN}

Semakin berkembang sebuah perusahan, semakin banyak tenaga kerja yang dibutuhkan untuk menggerakan kegiatan operasional. Selain itu dibutuhkan leader yang meningkat secara kualitas atau keahlian (skill) leadership juga diperlukan untuk mengimbangi kemajuan teknologi dan tenaga kerja yang semakin pesat pula. Sejalan dengan hal tersebut promosi jabatan akan memberikan peranan penting bagi setiap karyawan bahkan menjadi sebuah idaman dan tujuan yang selalu diharapkan. Promosi jabatan merupakan salah satu bagian dari penempatan yang dilaksanakan oleh perusahaan. Penempatan karyawan dilakukan dengan membuat penyesuaian terhadap kebutuhan perusahaan yang berhubungan dengan perencanaan untuk memperoleh orang yang tepat pada posisi yang tepat (the right man on the 
right place). Dengan demikian dibutuhkan pendidikan dan pelatihan, komitmen dan kompetensi karyawan untuk meningkatkan kualitas sumber daya manusia yang efktif dan efisien.

\section{Identifikasi Masalah}

Berdasarkan latar belakang masalah di atas maka identifikasi masalah dari penelitian ini adalah sebagai berikut:

1. Meningkatkan tanggung jawab dan peran serta karyawan dalam penyelenggaraan pendidikan dan pelatihan.

2. Perbaikan sumber daya manusia yang merupakan titik sentral sebagai pendorong peningkatan kualitas pelayanan secara berkelanjutan belum memadai.

3. Kompensasi yang diberikan oleh perusahaan belum mencukupi hidup layak bisa menjadi salah satu faktor yang menghambat dalam hal pekerjaan yang dilaksanakan oleh karyawan.

4. Kurangnya pengetahuan karyawan dalam mengelola atau memimpin sebuah organisasi.

5. Kurangnya pengetahuan dalam pengoperasian komputer sehingga peluang untuk mendapatkan promosi jabatan cenderung rendah.

6. Pengetahuan karyawan rendah karena karyawan tidak memiliki pemahaman dan wawasan yang luas tentang teori pendidikan dan pembelajaran sehingga berdampak pada promosi jabatan yang rendah.

7. Kemampuan dan ketrampilan karyawan dalam bekerja belum dapat diandalkan, sehingga promosi jabatan yang ditunjukkan karyawan cenderung berkurang bahkan semakin menurun.

8. Kurangnya pengetahunan dan kemampuan karyawan terhadap leadership sehingga karyawan ditutut untuk dapat dengan cepat dalam mengambil suatu keputusan.

9. Kesadaran karyawan yang rendah terhadap rasa memiliki dan tanggung jawab dengan pekerjaan.

10. Kurangnya kedisiplin karyawan sehingga peluang untuk mendapatkan promosi jabatan cenderung rendah.

\section{Rumusan Masalah}

Adapun rumusan masalah dari penelitian ini adalah sebagai berikut:

1. Apakah terdapat pengaruh pelaksanaan Program Pendidikan dan Pelatihan terhadap Promosi Jabatan di PT. Panarub Industri Tangerang?

2. Apakah terdapat pengaruh Komitmen terhadap Promosi Jabatan di PT. Panarub Industri Tangerang?

3. Apakah terdapat pengaruh Kompetensi terhadap Promosi Jabatan di PT. Panarub Industri Tangerang?

4. Apakah terdapat pengaruh pelaksanaan Program Pendidikan \& Pelatihan, Komitmen dan Kompetensi secara bersama-sama terhadap Promosi Jabatan di PT. Panarub Industri Tangerang?

\section{Tujuan Penelitian}

Dalam penyusunan penelitian ini untuk mempersempit pokok pembahasan penulis telah membuat suatu bentuk perumusan masalah sebagai berikut:

1. Untuk mengetahui dan menganalisis pengaruh pelaksanaan Program Pendidikan dan Pelatihan terhadap 
Promosi Jabatan di PT. Panarub Industry Tangerang.

2. Untuk mengetahui dan menganalisis pengaruh Komitmen terhadap Promosi Jabatan di PT. Panarub Industry Tangerang.

3. Untuk mengetahui dan menganalisis pengaruh Kompetensi terhadap Promosi Jabatan di PT. Panarub Industry Tangerang.

4. Untuk mengetahui dan menganalisis pengaruh pelaksanaan Program Pendidikan dan Pelatihan, Komitmen dan Kompetensi secara bersamasama terhadap Promosi Jabatan di PT. Panarub Industry Tangerang.

\section{KAJIAN TEORITIS DAN HIPOTESIS PENELITIAN \\ Promosi Jabatan}

Dalam buku Manajemen Sumber

Daya Manusia yang ditulis oleh Hasibuan Malayu S.P, 2007, mengatakan bahwa promosi adalah perpindahan yang memperbesar authority dan responbility karyawan ke jabatan yang lebih tinggi dari suatu organisasi sehingga kewajiban, hak, status, dan penghasilannya semakin besar.

\section{Kompetensi}

Menurut Siagian, Sondang $\mathrm{P}$, 2001. yang mengungkapkan bahwa, "kompetensi adalah suatu uraian keterampilan, pengetahuan dan sikap yang utama diperlukan untuk mencapai kinerja yang efektif dalam pekerjaan". Pengertian ini mencakup tiga unsur dari kompetensi, yaitu keterampilan, pengetahuan dan sikap yang diperlukan oleh seseorang untuk mencapai kinerja yang efektif.

\section{Komitmen}

Menurut Hadari Nawawi, 2005.

Menyatakan bahwa Komitmen organisasi adalah :

a. Suatu keinginan yang kuat untuk menjadi anggota dari organisasi tertentu.

b. Keinginan menuju level keahlian tinggi atas nama organisasi.

c. Suatu kepercayaan tertentu di dalam, dan penerimaan terhadap nilai-nilai dan tujuan organisasi tersebut.

\section{Pendidikan dan Pelatihan}

Menurut Sugiyono, 2005. Mengungkapkan bahwa pendidikan \& pelatihan adalah "Proses mengajarkan karyawan baru atau yang ada sekarang, ketrampilan dasar yang mereka butuhkan untuk menjalankan pekerjaan mereka". Pelatihan merupakan salah satu usaha dalam meningkatkan mutu sumber daya manusia dalam dunia kerja, baik karyawan yang baru ataupun yang sudah bekerja perlu mengikuti pelatihan karena adanya tuntutan pekerjaan yang dapat berubah akibat perubahan lingkungan kerja, strategi, dan lain sebagainya.

\section{Penelitian Terdahulu}

Dasar atau acuan yang berupa teori-teori atau temuan-temuan melalui hasil berbagai penelitian sebelumnya merupakan hal yang sangat perlu dan dapat dijadikan sebagai data pendukung. Salah satu data pendukung yang menurut peneliti perlu dijadikan bagian tersendiri adalah penelitian terdahulu yang relevan dengan permasalahan yang sedang dibahas dalam penelitian ini. Dalam hal ini, fokus penelitian terdahulu yang dijadikan acuan adalah terkait dengan masalah teknologi informasi. 
Oleh karena itu, peneliti melakukan langkah kajian terhadap beberapa hasil penelitian berupa tesis dan jurnal-jurnal terdahulu.

\section{Kerangka Pemikiran}

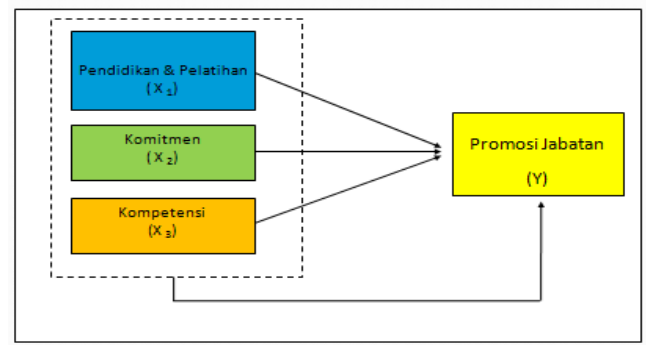

\section{METODE PENELITAN}

\section{Sampel dan Data}

Populasi dalam penelitian ini adalah seluruh Karyawan PT Panarub Industry Golongan A yang mengikuti program pendidikan dan pelatihan sebanyak 52 orang dan sampel dilakukan secara acak sederhana sebanyak 30 orang dengan menggunakan Rumus SLOVIN (Azhari, 2002:53)

$$
\begin{aligned}
\mathrm{n} & =\frac{N}{1+N(e)^{2}} \\
& =\frac{52}{1+52(0,1)^{2}} \\
& =30 \text { Sampel }
\end{aligned}
$$

Dimana :

$$
\begin{array}{rllr}
\mathrm{n} & = & \text { Jumlah Sampel } \\
\mathrm{N} \quad= & \text { Jumlah Populasi } \\
\mathrm{e} \quad= & \text { Error }(\% \text { yang dapat } \\
& \text { ditoleransi } & \text { terhadap } \\
& \text { ketidak } & \text { tepatan } \\
& \text { penggunaan } & \text { sampel } \\
& \text { sebagai } & \text { pengganti } \\
& \text { populasi) }
\end{array}
$$

\section{Instrumen Penelitian}

Bertolak dari indikator-indikator variabel penelitian yang diturunkan dari dimensi yang berlandaskan teori masing-masing variabel yang telah dibangun

1. Promosi Jabatan (Y)

Definisi konseptual (teori)

Definisi operasional (dari indikator dikembangkan menjadi 25 butir instrumen).

2. Pendidikan dan Pelatihan $\left(\mathrm{X}_{1}\right)$

Definisi konseptual (teori)

Definisi operasional (dari indikator dikembangkan menjadi 25 butir instrumen).

3. Komitmen $\left(\mathrm{X}_{2}\right)$

Definisi konseptual (teori)

Definisi operasional (dari indikator dikembangkan menjadi 25 butir instrumen).

4. Kompetensi (X3)

Definisi konseptual (teori)

Definisi operasional (dari indikator dikembangkan menjadi 25 butir instrumen).

\section{Teknik Analisa Data}

1. Analisis Regresi

Analisis Regresi Sederhana

- $\mathrm{Y}=\mathrm{a}+\mathrm{b} 1(\mathrm{X} 1)$

- $\mathrm{Y}=\mathrm{a}+\mathrm{b} 2(\mathrm{X} 2)$

2. Analisis Regresi Berganda

- $\mathrm{Y}=\mathrm{a}+\mathrm{b} 1 \mathrm{X} 1+\mathrm{b} 2 \mathrm{X} 2$

3. Hipotesis Statistik

a. Hipotesis Pertama

Ho : $\beta y 1=0 \quad$ Tidak terdapat pengaruh pendidikan \& pelatiahan terhadap promosi jabatan

Ha : $\beta y 1 \neq 0 \quad$ Terdapat pengaruh pendidikan \& pelatiahan 
terhadap

promosi jabatan

b. Hipotesis Kedua

Ho $: \beta y 2=0 \quad$ Tidak terdapat pengaruh komitmen terhadap promosi jabatan

Ha : $\beta y 2 \neq 0 \quad$ Terdapat pengaruh komitmen terhadap promosi

c. Hipotesis Ketiga

Ho $: \beta y 3=0 \quad$ Tidak terdapat pengaruh kompetensi terhadap promosi jabatan

Ha : $\beta \mathrm{y} 3 \neq 0 \quad$ Terdapat pengaruh kompetensi terhadap promosi jabatan

d. Hipotesis Keempat

Ho : $\beta$ y $1,2,3=0$

Tidak terdapat pengaruh pendidikan \& pelatiahan, komitmen dan Kompetensi secara bersama-sama terhadap promosi jabatan

Ha : $\beta$ y $1,2,3 \neq 0$

Terdapat pengaruh pendidikan \& pelatiahan, komitmen dan Kompetensi secara bersama-sama terhadap promosi jabatan

4. Uji Hipotesis

Uji F Hitung

Uji $\mathrm{F}$ dilakukan untuk mengecek apakah ada hubungan antara variabel-variabel $\mathrm{X} 1, \mathrm{X} 2$, dan $\mathrm{X}$ 3, dengan variabel $Y$. Pengujian tersebut dilakukan dengan alat bantu paket program SPSS (Statistical Package for Social Sciences) ver. 16.0 for windows, jika hipotesa nol ditolak berarti minimal ada satu variabel yang digunakan berpengaruh nyata terhadap variabel tidak bebas. Sebaliknya, jika hipotesa nol diterima berarti secara bersama variabel yang digunakan tidak bisa menjelaskan variasi dari variabel tidak bebas

5. Uji t hitung

Uji t dilakukan untuk mengecek apakah secara individual, masingmasing variabel $\mathrm{X}$ berpengaruh terhadap variabel Y. Pengujian tersebut dilakukan dengan alat bantu paket program SPSS (Statistical Package for Social Sciences) versi 16.0 for windows, jika hipotesa nol ditolak berarti variabel yang diuji berpengaruh nyata terhadap variabel tidak bebas. Sebaliknya, jika hipotesa nol diterima, maka variabel yang diuji tidak berpengaruh nyata terhadap variabel tidak bebas

\section{HASIL DAN PEMBAHASAN \\ Koefisien Korelasi}

Tabel 1

Koefisien Korelasi

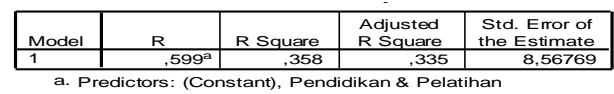

Koefisien korelasi antara pendidikan \& pelatihan dengan promosi jabatan sebesar 0,599, hal ini menunjukkan bahwa koefisien korelasi variabel pendidikan \& pelatihan dengan promosi jabatan mempunyai tingkat hubungan yang kuat. Karena berada pada interval koefisien $0,5-0,7$. Dengan demikian bahwa variabel bebas pendidikan \& pelatihan menunjukkan hubungan atau korelasi yang kuat dan searah dengan variabel terikat promosi jabatan.

Tabel 2

\section{Koefisien Korelasi}

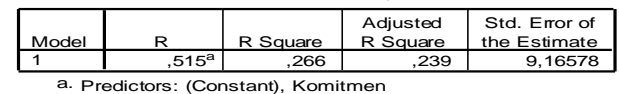


Koefisien korelasi antara Komitmen $\mathrm{X}_{2}$ dengan promosi jabatan sebesar 0,515, hal ini menunjukkan bahwa koefisien korelasi variabel Komitmen $\mathrm{X}_{2}$ dengan promosi jabatan mempunyai tingkat hubungan yang kuat. Karena berada pada interval koefisien 0,5 - 0,7. Dengan demikian bahwa variabel bebas Komitmen $\mathrm{X}_{2}$ menunjukkan hubungan atau korelasi yang kuat dan searah dengan variabel terikat promosi jabatan.

\section{Tabel 3}

\section{Koefisien Korelasi}

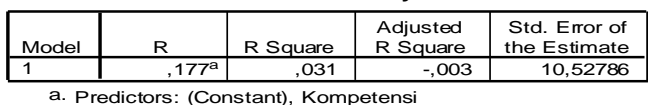

Kompetensi dengan promosi jabatan sebesar 0,177, hal ini menunjukkan bahwa koefisien korelasi variabel Kompetensi dengan promosi jabatan mempunyai tingkat hubungan yang lemah. Karena berada pada interval koefisien 0,5 - 0,7. Dengan demikian bahwa variabel bebas Kompetensi menunjukkan hubungan atau korelasi yang kuat dan searah dengan variabel terikat promosi jabatan.

Tabel 4

\section{Koefisien Korelasi}

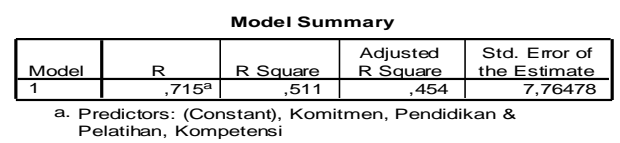

Koefisien korelasi antara pendidikan \& pelatihan dengan promosi jabatan sebesar 0,715 , hal ini menunjukkan bahwa koefisien korelasi variabel pendidikan \& pelatihan $\left(\mathrm{X}_{1}\right)$, Komitmen ( $\left.\mathrm{X}_{2}\right)$, Kompetensi ( $\mathrm{X}_{3}$ ), dengan promosi jabatan mempunyai tingkat hubungan yang kuat. Karena berada pada interval koefisien 0,5 - 0,7 Dengan demikian bahwa variabel bebas pendidikan \& pelatihan $\left(\mathrm{X}_{1}\right)$, Komitmen $\left(\mathrm{X}_{2}\right.$ ), Kompetensi ( $\left.\mathrm{X}_{3}\right)$ menunjukkan hubungan atau korelasi yang kuat dan searah dengan variabel terikat promosi jabatan

Tabel 5

Koefisien Determinasi

\begin{tabular}{|c|c|c|c|c|}
\hline No. & Hubungan & $r$ & Keterangan & Determinan \\
\hline 1. & $X_{1} \longrightarrow Y$ & 0,599 & $\begin{array}{l}\text { Positif } \\
\text { Kuat }\end{array}$ & $\begin{aligned} R & =(r)^{2} \times 100 \% \\
& =(0.599)^{2} \times 100 \% \\
& =35,88 \%\end{aligned}$ \\
\hline 2. & $X_{2} \longrightarrow Y$ & 0,515 & $\begin{array}{r}\text { Positif } \\
\text { Kuat }\end{array}$ & $\begin{aligned} R & =(r)^{2} \times 100 \% \\
& =(0.515)^{2} \times 100 \% \\
& =26,53 \%\end{aligned}$ \\
\hline 3 & $X_{3} \longrightarrow Y$ & 0,177 & $\begin{array}{l}\text { Negatif } \\
\text { Lemah }\end{array}$ & $\begin{aligned} R & =(r)^{2} \times 100 \% \\
& =(0.177)^{2} \times 100 \% \\
& =3,13 \%\end{aligned}$ \\
\hline 4 & $\begin{array}{l}X_{1} \\
X_{2} \\
X_{3}\end{array} \longrightarrow Y$ & 0,715 & $\begin{array}{c}\text { Positif } \\
\text { Kuat }\end{array}$ & $\begin{aligned} R & =(r)^{2} \times 100 \% \\
& =(0.715)^{2} \times 100 \% \\
& =51.1 \%\end{aligned}$ \\
\hline
\end{tabular}

1. Nilai koefisien determinasi atau $R$ Squer sebesar 0,358. Hal ini menunjukkan $35,88 \%$ variabel promosi jabatan ditentukan oleh pendidikan dan pelatihan.

2. Nilai koefisien determinasi atau $R$ Squer sebesar 0,2653. Hal ini menunjukkan $26,53 \%$ variabel promosi jabatan ditentukan oleh Komitmen.

3. Nilai koefisien determinasi atau $R$ Squer sebesar 0,0313. Hal ini menunjukkan $3,13 \% \quad$ variabel promosi jabatan ditentukan oleh Kompetensi.

4. Nilai koefisien determinasi atau $R$ Squer sebesar 0,511. Hal ini menunjukkan $51,1 \%$ variabel promosi jabatan ditentukan oleh pendidikan \& pelatihan, komitmen dan kompetensi, sedangkan sisanya 48.9\% ditentukan faktor-faktor lain.

\section{Persamaan Regresi}

Adapun persamaan regresi dalam penelitian ini adalah sebagai berikut: 
Tabel 5

Persamaan Regresinya pengaruh

Pendidikan \& Pilatihan $\mathrm{X}_{1}$ terhadap Promosi Jabatan (Y)

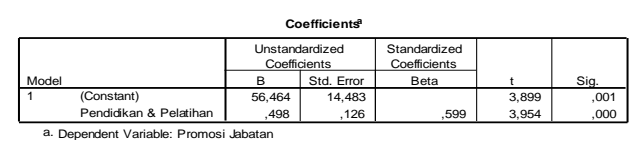

$\mathrm{X}_{1}$ nilainya positif artinya variabel ini berpengaruh signifikan terhadap promosi jabatan (Y) dan searah, sehingga apabila variabel-variabel bebas tersebut mengalami kenaikan, maka nilai variabel terkait juga mengalami kenaikan atau sebaliknya. Untuk pendidikan dan pelatihan $\left(\mathrm{X}_{1}\right): 0,498$ artinya apabila pendidikan dan pelatihan meningkat 0,498 maka akan meningkatkan promosi jabatan sebesar 0,498 satuan.

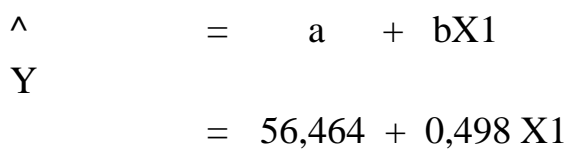$$
=56,464+0,498 \times 1
$$

Tabel 6

Persamaan Regresinya pengaruh Komitmen $\mathrm{X}_{2}$ terhadap Promosi Jabatan (Y)

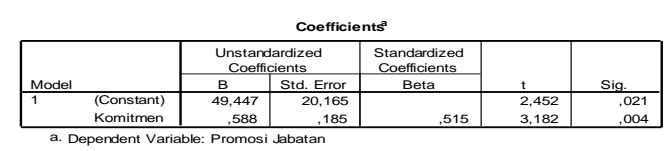

$\mathrm{X}_{2}$ nilainya positif artinya variabel ini berpengaruh signifikan terhadap promosi jabatan (Y) dan searah, sehingga apabila variabel-variabel bebas tersebut mengalami kenaikan, maka nilai variabel terkait juga mengalami kenaikan atau sebaliknya. Untuk Komitmen $\left(\mathrm{X}_{2}\right)$ : 0,588 artinya apabila Komitmen meningkat 0,588 maka akan meningkatkan promosi jabatan sebesar 0,588 satuan.

$$
\begin{array}{llc}
\wedge & = & a+b X 2 \\
\mathrm{Y} & = & 49,447+0,588 \times 2
\end{array}
$$

Tabel 7

Persamaan Regresinya pengaruh Kompetensi $\mathrm{X}_{3}$ terhadap Promosi Jabatan (Y)

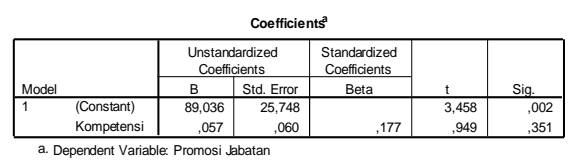

$\mathrm{X}_{3}$ nilainya positif artinya variabel ini berpengaruh signifikan terhadap promosi jabatan (Y) dan searah, sehingga apabila variabel-variabel bebas tersebut mengalami kenaikan, maka nilai variabel terkait juga mengalami kenaikan atau sebaliknya. Untuk Kompetensi $\left(\mathrm{X}_{3}\right)$ : 0,057 artinya apabila Kompetensi meningkat 0,057 maka akan meningkatkan promosi jabatan sebesar 0,057 satuan

$$
\begin{array}{ll}
\wedge & =a+b X 3 \\
\mathrm{Y} & =89,036+0,057 \mathrm{X} 3
\end{array}
$$

\section{Tabel 8}

Persamaan Regresi Berganda persamaan regresi linear berganda antaravariabel bebas pendidikan \& pelatihan $\left(\mathrm{X}_{1}\right)$, Komitmen $\left(\mathrm{X}_{2}\right)$, Kompetensi $\left(\mathrm{X}_{3}\right)$, dengan promosi jabatan (Y).

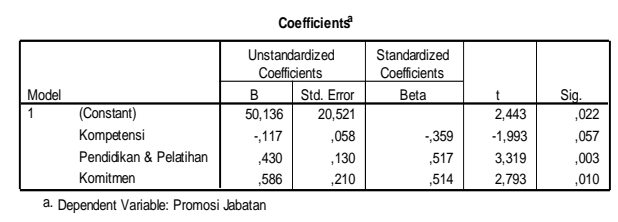

$$
\begin{aligned}
\mathrm{Y} & = \\
& = \\
\wedge & \mathrm{b}_{0}+\mathrm{bX}_{1} \\
& \mathrm{bX}_{2}+\mathrm{bX}_{3}
\end{aligned}
$$


Y

$$
=\begin{aligned}
& 50,136+0,430 \mathrm{X}_{1}+ \\
& 0,586 \mathrm{X}_{2}+\left(-0.117 \mathrm{X}_{3}\right)
\end{aligned}
$$

Angka-angka yang terdapat didalam kurung adalah merupakan besarnya nilai $\mathrm{t}$ hitung, dari masingmasing variabel bebas, dimana variabel pendidikan dan pelatihan $\left(\mathrm{X}_{1}\right)$ dan Komitmen $\left(\mathrm{X}_{2}\right)$, nilainya positif artinya variabel ini berpengaruh signifikan terhadap promosi jabatan (Y) dan searah, sehingga apabila variabelvariabel bebas tersebut mengalami kenaikan, maka nilai variabel terkait juga mengalami kenaikan atau sebaliknya. Untuk Kompetensi $\left(\mathrm{X}_{3}\right)$ nilai konstanta sebesar -0,117 menyatakan bahwa jika tidak ada Kompetensi promosi jabatan akan menurun sebesar 0.117 , maka nilai variabel terikat juga akan meningkatkan promosi jabatan atau sebaliknya.

Sedangkan nilai intersep dan nilai koefisien dari masing-masing variabel diantaranya pendidikan \& pelatihan (X 1), Komitmen ( $\left.\mathrm{X}_{2}\right)$, Kompetensi $\left(\mathrm{X}_{3}\right)$, dengan promosi jabatan (Y) dalam persamaan tersebut di atas dapat diuraikan sebagai berikut :

Untuk pendidikan \& pelatihan $\left(X_{1}\right): 0,430$ artinya apabila pendidikan $\&$ pelatihan meningkat 0,430 maka akan meningkatkan promosi jabatan sebesar 0,430 satuan.

Untuk Komitmen $\left(\mathrm{X}_{2}\right)$ : 0,586 artinya apabila Komitmen karyawan meningkat sebesar 0,586 maka akan meningkatkan promosi jabatan sebesar 0,586 satuan.

Untuk Kompetensi $\left(\mathrm{X}_{3}\right)$ : ($0,117)$ artinya apabila Kompetensi karyawan menurun sebesar 0,117 maka akan menurun kan promosi jabatan sebesar 0,117 satuan.

\section{Hasil Penelitian}

Menurut analisis penulis bahwa pengaruh antara pendidikan dan pelatihan, Komitmen dan kompetensi terhadap promosi jabatan di PT Panarub Industry, signifikan. Berdasarkan hal tersebut di atas bahwa pendidikan dan pelatihan, komitmen dan kompetensi perlu dipertegas dan dioptimalkan dalam promosi jabatan yang dilaksanakan oleh PT Panarub Industry. Dalam pembahasan hasil penelitian ini dilakukan dalam dari empat segi, yaitu hasil analisis pengaruh antara variabel dan hasil analisis tiap variabel yang menunjukkan bahwa:

1. Pengaruh pendidikan dan pelatihan terhadap promosi jabatan di PT Panarub Industry Tangerang.

Dari hasil analisis diperoleh nilai koefisien determinasi atau $\mathrm{R}$ Square sebesar 0,358. Hal ini menunjukkan $35,88 \%$ variabel promosi jabatan (Y) ditentulan oleh faktor variabel pendidikan dan pelatihan (X1), sedang sisanya $64,12 \%$ ditentukan oleh faktor lain, yang dalam penelitian ini tidak diteliti.

Dari hasil perhitungan, diperoleh nilai $t_{\text {hitung }}$ sebesar 3,954 Dengan demikian $t_{\text {hitung }}>t_{\text {tabel }}$, sehingga jelas Ho ditolak dan $\mathrm{Ha}$ diterima. Hal ini menunjukkan bahwa pendidikan dan pelatihan berpengaruh positif dan signifikan terhadap promosi jabatan di PT Panarub Industry Tangerang.

2. Pengaruh komitmen terhadap promosi jabatan di PT Panarub Industry Tangerang. 
Dari hasil analisis diperoleh nilai koefisien determinasi atau $\mathrm{R}$ Square sebesar 0,266. Hal ini menunjukkan $26,63 \%$ variabel promosi jabatan (Y) ditentulan oleh faktor variabel komitmen (X2), sedang sisanya $73,37 \%$ ditentukan oleh faktor lain, yang dalam penelitian ini tidak diteliti.

Dari hasil perhitungan, diperoleh nilai $t_{\text {hitung }}$ sebesar 3,182 Dengan demikian $t_{\text {hitung }}>t_{\text {tabel }}$, sehingga jelas Ho ditolak dan $\mathrm{Ha}$ diterima. Hal ini menunjukkan bahwa komitmen berpengaruh positif dan signifikan terhadap promosi jabatan di PT Panarub Industry Tangerang.

3. Pengaruh kompetensi terhadap promosi jabatan di PT Panarub Industry Tangerang.

Dari hasil analisis diperoleh nilai koefisien determinasi atau $\mathrm{R}$ Square sebesar 0,031. Hal ini menunjukkan $3,13 \% \quad$ variabel promosi jabatan $(\mathrm{Y})$ ditentulan oleh faktor variabel kompetensi (X3), sedang sisanya $96,87 \%$ ditentukan oleh faktor lain, yang dalam penelitian ini tidak diteliti.

Dari hasil perhitungan, diperoleh nilai $t_{\text {hitung }}$ sebesar 0,949 Dengan demikian $\mathrm{t}_{\text {hitung }}>\mathrm{t}_{\text {tabel }}$, sehingga jelas Ho ditolak dan $\mathrm{Ha}$ diterima. Hal ini menunjukkan bahwa pendidikan dan pelatihan berpengaruh positif dan signifikan terhadap promosi jabatan di PT Panarub Industry Tangerang.

4. Pengaruh pendidikan dan pelatihan, komitmen dan kompetensi terhadap promosi jabatan di PT Panarub Industry Tangerang.

Dari hasil analisis diperoleh nilai koefisien determinasi atau $\mathrm{R}$
Square sebesar 0,511. Hal ini menunjukkan $51,1 \%$ variabel promosi jabatan (Y) ditentulan oleh faktor variabel pendidikan dan pelatihan (X1), komitmen (X2), kompetensi (X3) secara bersamasama, sedang sisanya $48,9 \%$ ditentukan oleh faktor lain, yang dalam penelitian ini tidak diteliti.

Dari hasil perhitungan, diperoleh nilai $F_{\text {hitung }}$ sebesar 9,043 seperti terlihat tabel. Dengan demikian $F_{\text {hitung }}>F_{\text {tabel }}$, sehingga jelas $\mathrm{H}_{\mathrm{o}}$ ditolak dan $\mathrm{H}_{\mathrm{a}}$ diterima. Hal ini menunjukkan bahwa secara bersama-sama pendidikan dan pelatihan, komitmen dan kompepensi berpengaruh positif dan signifikan terhadap promosi jabatan di PT Panarub Industry Tangerang.

\section{BAB V KESIMPULAN DAN KETERBATASAN \\ Kesimpulan}

1. Pada uji berganda diperoleh nilai $\mathrm{F}_{\text {hitung }}>\mathrm{F}_{\text {tabel. }}$. Hal ini menunjukkan bahwa secara bersama-sama pendidikan dan pelatihan, komitmen dan kompetensi berpengaruh signifikan terhadap promosi jabatan, sehingga jelas Ho ditolak dan $\mathrm{Ha}$ diterima, hal ini menunjukan bahwa pendidikan dan pelatihan, komitmen dan kompetensi secara bersama sama dapat digunakan untuk stimulasi dalam promosi jabatan di PT Panarub Industry.

2. Berdasarkan hasil perhitungan dengan uji $t$, diperoleh nilai $t_{\text {hitung }}>$ $t_{\text {tabel. }}$ Hal ini menunjukkan bahwa pendidikan dan pelatihan, komitmen dan kompetensi mempunyai pengaruh yang signifikan terhadap promosi jabatan, sehingga jelas Ho 
ditolak dan $\mathrm{Ha}$ diterima, hal ini menunjukan bahwa pendidikan dan pelatihan, komitmen dan kompetensi dapat digunakan untuk stimulasi dalam promosi jabatan di PT Panarub Industry.

3. Demikian dengan hasil perhitungan variabel kemampuan kerja $t_{\text {hitung }}>$ $t_{\text {tabel. }} \quad$ Hal ini menunjukkan bahwa pendidikan dan pelatihan, komitmen dan kompetensi mempunyai pengaruh yang signifikan terhadap promosi jabatan di PT Panarub Industry sehingga jelas Ho ditolak dan Ha diterima, hal ini menunjukan bahwa pendidikan dan pelatihan, komitmen dan kompetensi dapat meningkatkan promosi jabatan di PT Panarub Industry.

\section{DAFTAR PUSTAKA}

Achmad S. Ruky, 2001. Sistem Manajemen Peningkatan Mutu Sumber Daya Manusia. PT. Gramedia, Jakarta.

Agus Eko Sujianto, 2009. Aplikasi Statistik dengan SPSS 16.0, PT. Prestasi Pustakaraya, Jakarta.

Hadari Nawawi, 2005. Manajemen Sumberdaya Manusia, Gajah Mada University Press, Yogyakarta.

Hani, T. Handoko, 2001. Manajemen Personalia dan Sumber Daya Manusia. Edisi ke-2. BPFE. Yogyakarta.

Hasibuan, Malayu S.P, 2007. Manajemen Sumberdaya Manusia, Bumi Aksara, Jakarta. Husein Umar, 2003. Riset Sumber Daya Manusia dalam Organisasi, PT Gramedia Pustaka Utama, Jakarta.
Keith David, 2001. Perilaku Dalam Organisasi, Penerbit Erlangga, Jakarta.

Mangkunegara Anwar Prabu, 2002. Manajemen Sumberdaya Perusahaan, Cetakan Keempat, PT. Remaja Rosdakarya, Bandung.

Nasution, Mulia, 2000. Manajemen Personalia Aplikasi Dalam Perusahaan. Djambaran, Jakarta.

Robert L. Malthis, 2002. Manajemen Sumberdaya Manusia, Buku 1, Salemba Empat, Jakarta.

Robert L. Malthis, 2002. Manajemen Sumberdaya Manusia, Buku 2, Salemba Empat, Jakarta.

Siagian, Sondang P, 2001. Manajemen Sumberdaya Manusia, Bumi Aksara, Jakarta.

Slovin Azhari, 2002. Mengolah Data Statistik Secara Profesional, PT. Elex Media Computindo, Jakarta.

Sugiyono, 2005. Metode Penelitian Pendidikan, Pendekatan Kuantitatif, Kualitatif dan $R \& D$, Alfabeta. Bandung. 